Article

\title{
Factors Influencing the Acceptance of Mobile Collaborative Learning for the Continuous Professional Development of Teachers
}

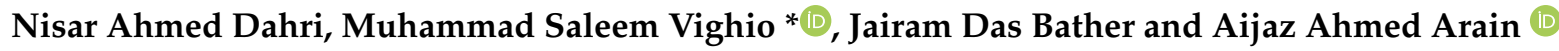 \\ Faculty of Science, Quaid-e-Awam University of Engineering, Science and Technology, \\ Nawabshah 67480, Pakistan; dahrinisar@gmail.com (N.A.D.); jairam@quest.edu.pk (J.D.B.); \\ aijaz@quest.edu.pk (A.A.A.) \\ * Correspondence: saleem.vighio@quest.edu.pk
}

Citation: Dahri, N.A.; Vighio, M.S.; Bather, J.D.; Arain, A.A. Factors Influencing the Acceptance of Mobile Collaborative Learning for the Continuous Professional Development of Teachers. Sustainability 2021, 13, 13222. https:// doi.org/10.3390/su132313222

Academic Editor: Eila Jeronen

Received: 28 October 2021

Accepted: 22 November 2021

Published: 29 November 2021

Publisher's Note: MDPI stays neutral with regard to jurisdictional claims in published maps and institutional affiliations.

Copyright: (c) 2021 by the authors. Licensee MDPI, Basel, Switzerland. This article is an open access article distributed under the terms and conditions of the Creative Commons Attribution (CC BY) license (https:/ / creativecommons.org/licenses/by/ $4.0 /)$.

\begin{abstract}
The COVID-19 epidemic has not only triggered a worldwide health catastrophe, it has also affected learning processes all over the world. While COVID-19 was in its initial wave of transmission, educational systems around the world witnessed bitter experiences in the form of the closure of institutes or a shift to distance (or online) learning techniques. The delivery of quality education was affected the most where the educational system was already weak due to the unavailability of effective teachers' professional development programs and the lack of the integration of technology. This study extends the conventional continuous professional development (CPD) model of in-service teachers adopted in the province of Sindh, Pakistan. The extensions are based on the integration of mobile technology and support for collaborative learning and ongoing assistance, which are missed in the current traditional model. To assess the acceptance and use of the app, an Mobile collaborative learning (MCL) based CPD acceptance framework is designed by combining chosen components from a generally recognized Unified theory of acceptance and use of technology (UTAUT2) and other well-recognized acceptance models for the acceptance and use of the technology. In the context of CPD, a total of 14 constructs have been selected which include performance expectancy; effort expectancy; facilitating conditions; hedonic motivation; mobility; knowledge acquisition; content and information quality; on-the-job support; reward; behavioral intention; engagement; interactivity with peer \& experts; self-management and collaborative learning. Based on these constructs; a total of 13 hypotheses were developed with 55 measurement items. A total of 494 teachers participated in a two-week training session using the designed app. Based on the activity, a questionnaire was designed and distributed among the participants using WhatsApp groups during the academic year of 2021-2022. Out of 494 participants; 472 participants correctly filled in the questionnaires, which were selected for analysis. The data was analyzed using IBM SPSS version 21; and, for Structural Equation Modeling (SEM) analysis, IBM AMOS version 21 was used. According to the results, all thirteen hypotheses were found statistically significant showing the positive impact on the acceptance and use of the CPD app. The results of this study promote teachers' and experts' engagement and participation in CPD activities which not only improve the knowledge and skills of the learners but also impact their long-term professional development and success. This research may help the teachers' training and related institutions to make better choices and develop a mobile collaborative learning system for school-based teacher support and training programs. As a basis, this study may also be used in other provinces of Pakistan and beyond to make it a CPD standard.
\end{abstract}

Keywords: COVID-19; CPD; ICT; Collaborative learning; UTAUT2 model; teachers' professional development

\section{Introduction}

The issue of sustainability and access to high-quality education has been a worldwide concern. In all educational institutes, teachers play a crucial role in the teaching and 
learning process. Properly designed professional development programs are the key to the success of the teaching process and imparting quality education. However, the learning outcomes of most of the institutes (especially in under-developed countries) are below the mark due to the dependency on ineffective conventional continuous professional development (CPD) programs which miss the integration of the latest teaching and learning trends. The recent COVID-19 pandemic has further escalated the situation and has badly affected the motivation, interest, and engagement of teachers and students in their subject matters. According to various studies, professional development deserves more attention than any other requirement [1,2]. Continuous professional development (CPD) training programs include a variety of topics that are relevant to all instructors, including teaching techniques, classroom management, interactive teaching, and specific courses and material. It is a lifelong process that continues throughout the professional careers of teachers to provide them equal professional development opportunities regardless of their gender to retain their teaching competence, expand knowledge, skills, and abilities to improve learning outcomes. However, many educational institutes (especially in under-developed countries) fall short of meeting sustainable development goals due to the lack of proper teachers' professional development programs. A review of continuous professional development (CPD) in Pakistan reveals several inconsistent policy decisions for establishing educational institutes at different levels [2,3]. The lack of trained resource personnel and subject specialists in Pakistan makes any CPD system difficult to execute. Moreover, the shortage of staff, lack of cadre jobs, and financial constraints are also major reasons for the failures of current CPD paradigms [4-9]. In [3], Chaudhary et al. state that CPD for teachers is uncommon in Pakistan, and when it exists, it is conventional and fails to satisfy the requirements of teachers.

In the province of Sindh, conventional CPD models such as the cascade model or the top-down training technique are used for years, which has major limitations due to the lack of the integration of technology, no follow-up assistance, and transmission loss or the dilution of information [1,10]. Provincial assessment surveys report highlights, in metrics such as the 2017 SAT (Standardized Achievement Test), that teachers in government schools, both at primary and secondary levels, are mostly under-qualified and insufficiently trained. They lack the minimum level of competency in basic subjects such as languages, mathematics, and science, without notable success [11]. According to the National Education Policy Framework 2017, teachers in Pakistan have inadequate subject knowledge and pedagogical abilities. Existing teacher development programs are not standardized and do not provide enough support for teachers' quality improvement [12].

Since 2010, provincial policies and practices have increasingly emphasized the use of ICT in the teaching and learning process, typically as a method of improving the quality of education [13-15]. Technology-supported learning has enormous potential to support teacher development $[14,15]$. UNESCO implemented mobile learning projects for teacher development in Nigeria, Senegal, Pakistan, and Mexico to enhance teaching effectiveness worldwide $[15,16]$. The major development areas under these projects were ECCE (Early Childhood and Care Education), mathematics, Spanish, and English. For this, a local teacher-training institute was involved in each project to ensure local buy-in and educational relevance for the participants $[17,18]$. However, the present modalities of CPD being used in Pakistan and Sindh by various CPD-imparting institutions do not consider the use of the technology and modern teaching (or learning) trends for the professional development of teachers. In the modern world, the use of technology (such as the use of mobile learning apps) for teachers' professional development as an innovative teaching approach has been highly recommended [15].

The market value for mobile learning applications and services has grown from $\$ 5$ to $\$ 70$ billion [19]. By delivering low-cost and easy-to-implement solutions, mobile technologies have improved access to education and provided extensive opportunities for the teaching and learning process anywhere and at any time [4]. Recently, mobile technologies have been widely utilized by several advanced nations for the ongoing professional devel- 
opment of teachers in their ministries [5]. Many studies suggest that ongoing professional development techniques for teachers' education can make the best use of mobile learning pedagogies to increase teacher collaboration and peer feedback, allow for reflection on teaching, assist in sharing classroom practice, and assess performance [18]. The portability feature of a mobile platform has also enabled the teachers to receive and share material from a variety of locations rather than just a single professional development location [20]. The portability and mobility feature of mobile technology helps to meet the sustainable development goals of SDG-4 Education 2030 by producing an increasing number of qualified teachers without the constraints of time, space, and finance [21]. Another important aspect of mobile is social interactivity, support for teachers' collaboration, and creating a network by connecting them with experts, mentors, peers, and their students [18].

Though the use of mobile technology for teachers' education is increasing, most of the apps have focused on individual learning, leaving gaps for activities that require collaboration in the context of the CPD of teachers. Collaborative learning allows multiple participants to share ideas, knowledge, experience, and resources to enhance professional and pedagogical competence [22,23]. Numerous studies have highlighted the social, psychological, and academic benefits of collaborative learning $[23,24]$. With its feature on a social support system, collaborative learning promotes learner-centered instruction, a positive attitude, critical thinking, and an active learning environment [24]. In a recent study, Nisar et al. conducted a review of newly commissioned research papers from the year 2010 to 2018 on technology-assisted collaborative learning. Some major results showed that the most common collaborative learning environments are based in the Web, computers, and mobile phones. However, these learning environments are still in their infancy. Due to its increasing importance, collaborative learning is being offered using platforms such as Skype, Facebook, Google applications, and other digital means to extend collaborative learning outside of the classroom [4]. However, none of the platforms have specifically focused on training for teachers' professional development.

\section{Mobile Collaborative Learning Framework for the CPD of Teachers}

The current CPD model for the continuous professional development of teachers misses the important aspect of the involvement of technology and support for collaborative learning and ongoing assistance. Based on the benefits of the use of technology, this study extends the existing CPD model for the professional development of schoolteachers in the province of Sindh. Figure 1a shows the conventional CPD model currently being used for the CPD of teachers. The CPD process begins with the students' needs identified using large-scale assessment reports (SAT, PEACe) based on provincial/national curriculum standards. In the next step, teachers' professional needs are identified through various methods such as a teachers' need analysis (TNA) using national professional standards for teachers in Pakistan, students' progress reports, classroom assessments, and so on. The third step is based on steps one and two in which CPD activities are identified according to targeted subject areas and the needs that emerged in steps one and two. The fourth step is the development and implementation of CPD activities/materials. The next phase provides ongoing (face-to-face) support through mentoring and peer coaching with the help of experts and field visits. Finally, the evaluation of the CPD program is carried out to measure the impact and outcome of the CPD interventions [10,25]. 

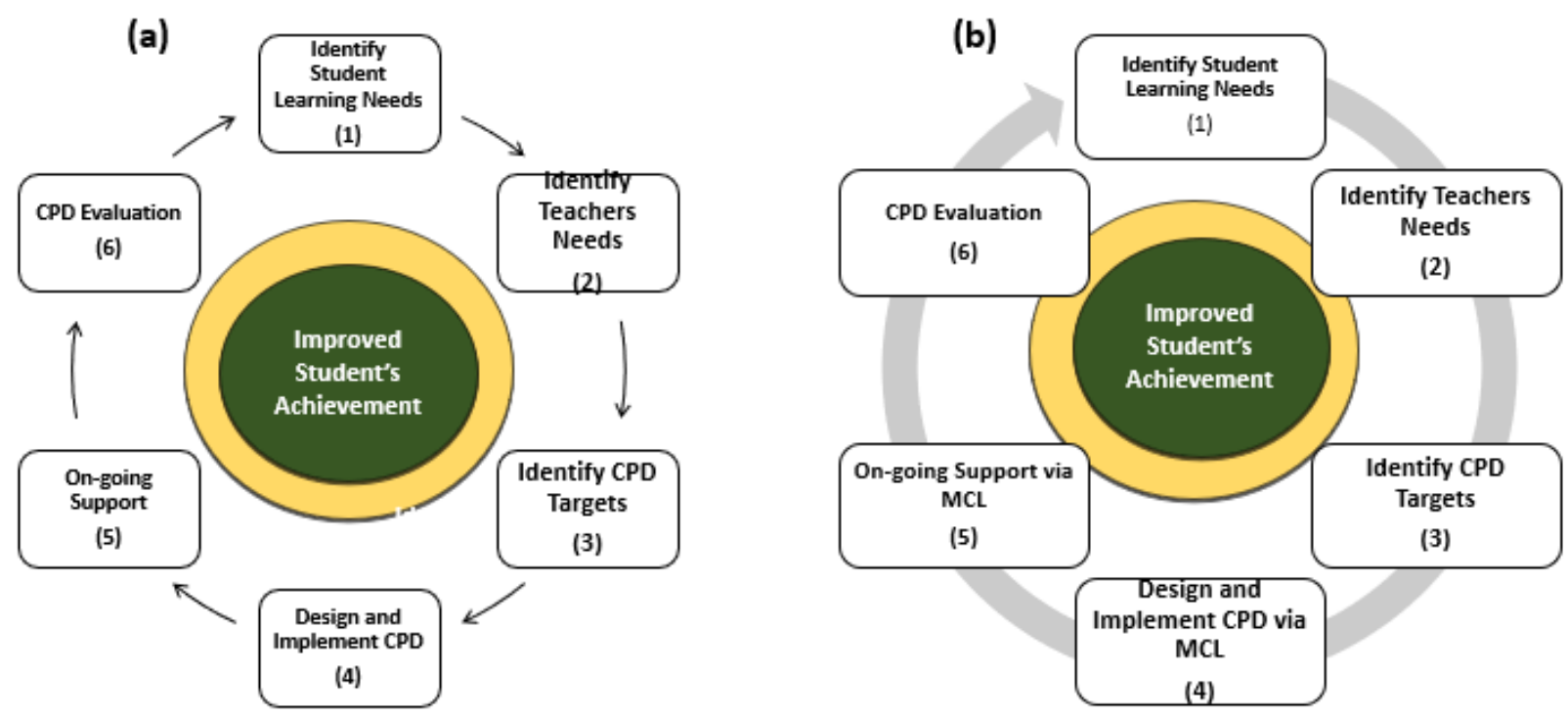

Figure 1. (a). Conventional CPD Model [25]; (b). Enhanced CPD Model.

Figure $1 \mathrm{~b}$ proposes extensions to the existing CPD model teachers' education.

Under the MCL-based approach, course activities are designed to provide support for online training sessions, the sharing of content (using audio, video, text, images, support material, etc.), group work and peer discussion, and assessment (using MCQs, quizzes, CRQs, and ERQs). Besides that, the teachers are provided ongoing support to discuss content and pedagogical issues that they encounter while teaching in the schools. The implementation of the MCL-based CPD is very cost-effective and efficient, as it reduces the implications of budget, time, and management encountered in face-to-face training delivery.

Under this extended CPD model, initially, the clusters of targeted schools are formed at the Taluka level with each cluster consisting of 15-20 schools. From each cluster, guide teachers (GTs) are selected for the training and mentoring of teachers. First, the GTs will attend a training program at the Taluka level using the MCL app. The TEI (Teacher Education Institute) experts will lead the training of GTs, then the trained GTs will provide training and assist teachers in their respective clusters. The school teachers will receive all types of training from time to time such as CPD training, mandatory training (induction and promotion training), and academic or professional progression courses. Afterward, GTs will work as subject mentors for providing mentoring support to teachers. Each GT will hold at least one meeting with the teachers to discuss the problem(s) the teachers have come across to find out the solution(s). The problem may be in the content area and/or pedagogy of the subject.

The GTs of the same Taluka will meet online with designated TEI experts of their clusters to discuss the issues and their solutions. Moreover, the GTs will post the problems of the teachers from time to time on the expert's forum for their resolution.

All the GTs will have a day-long conference with TEI experts to discuss important problems and issues that occurred during the quarter. In the meeting, sample work of students including answer sheets of quarterly assessments will also be analyzed to monitor student progress and to identify misconception(s), if any.

The TEI experts' responsibilities are to conduct the training of GTs, share recent developments in the teaching, provide time-to-time support for GTs, and discuss content and pedagogical problems faced by the teachers in their respective schools. All these activities will jointly be supervised by the school administration (primary and elementary) and the head of the TEI in the district to monitor the overall progress of CPD activities. 


\section{The MCL App}

To conduct the CPD of teachers in designated clusters and schools, a mobile app has been developed. The app gives support to teachers, GTs, and TEIs to meet, discuss and share context information anywhere and anytime to improve teaching and learning performance efficiently and cost-effectively.

The app gives support to teachers, GTs, and TEIs experts to create their profiles for the designated schools and clusters.

The teachers' profile allows them to register for activities such as CPD training (workshops, CPD courses, promotion linked training, etc.) supported using text, video/audio content, polls, quizzes, group assignments, discussion forums, announcements, progress levels, and pre and post-tests.

The ongoing support feature of the app provides support for direct collaboration between teachers and experts (GTs, TEIs experts) to meet, discuss, and share problems and their solutions. Additional mentoring support is also available to the teachers using the support forum, where they can obtain feedback from peers, GTs, and TEI experts. The app also includes features such as:

- the activity calendar for CPD activities,

- live interactive sessions (in built-in live sessions by experts with teachers),

- collaborative tools (where teachers collaboratively work on any assignment/task),

- discussion forums \& chat rooms (to share resources and information in any form with peers, GTs, and experts),

- $\quad$ resources (all types of resources required for teachers at the school levels including textbooks, Training Guides, Teachers' guides, Curriculum, Lesson plans, worksheets, Handouts, Videos, and so on),

- progress indicator (teachers can monitor their progress through a dashboard that includes graphs, timelines, percentages, a progress bar, and graphs) and rewards (teachers' ratings, course certifications, career progression, and achievements),

- help \& FAQs (help manual and ICT experts available anytime for technical assistance and FAQs for teachers' ease).

Besides the many benefits of the mobile app, the factors that influence users' intentions to accept mobile technology in the context of professional development, particularly in developing countries, have not been adequately investigated. Mobile applications are becoming increasingly popular around the world, so as a result, it is necessary to investigate the factors that influence teachers' intentions regarding the use of mobile-based professional development.

\section{Theoretical Model and Hypotheses Development}

Literature studies suggest that many theories and models exist to analyze users' intention to adopt and utilize the new technologies [26,27]. For example, Davis et al. [27] invented TAM (Technology Acceptance Model), which was expanded to TAM2 by Venkatesh et al. [28]. Fishbein et al. [29] produced the TRA (Theory of Reasoned Action), which was extended to the TBP (Theory of Planned Behavior) by Icek Ajzen [30]. Other researchers adopted, modified, and verified existing models and theories to provide insight and forecast technological adoption and usage [28,30]. Many academics have compared these models to determine which are the most relevant models and theories for forecasting technological acceptance [28]. The unified theory of acceptance and use of technology (UTAUT) [26] is the well-defined and resilient paradigm for the use of technology. The UTAUT framework's fundamental components are performance expectancy, effort expectancy, facilitating conditions, motivation, and social influence. However, in 2012, Venkatesh et al. [31] produced UTAUT2 (an expanded version of UTAUT) that includes three new constructs: hedonic motivation, habit, and price value. This study uses the UTAUT2 framework because of its excellent explanatory power and empirical replications [31]. The primary goal of this study is to identify the most significant influencing factors for the acceptance of MCLbased continuing professional development for teachers. To meet the requirements, our 
enhanced CPD model extends the UTAUT2 model by incorporating new features including CPD (knowledge acquisition (KA), content and information quality (CIQ), support $(\mathrm{S})$, and reward (R), mobile technology (Mobility (M), and collaborative learning (collaborative learning (CL)) interactivity with peers, experts (INT), engagement (ENG), and self-management $(\mathrm{SM})$ ) in addition to its own constructs including performance expectancy (PE), effort expectancy (EE), facilitation condition (FC), hedonic motivation (HM), and behavioral intention (BI). Moreover, constructs such as price value and habit have been excluded from the proposed CPD model as our CPD app is free of charge and is used only when it is demanded. The significant factors from the educational and training point of view are derived from an elaborated literature review for a better understanding of mobile usage and collaborative learning constructs and the relationship between them. Figure 2 shows the theoretical research model and hypothesis considered for this study. The details of each of the constructs and hypotheses are provided in Table 1 below.

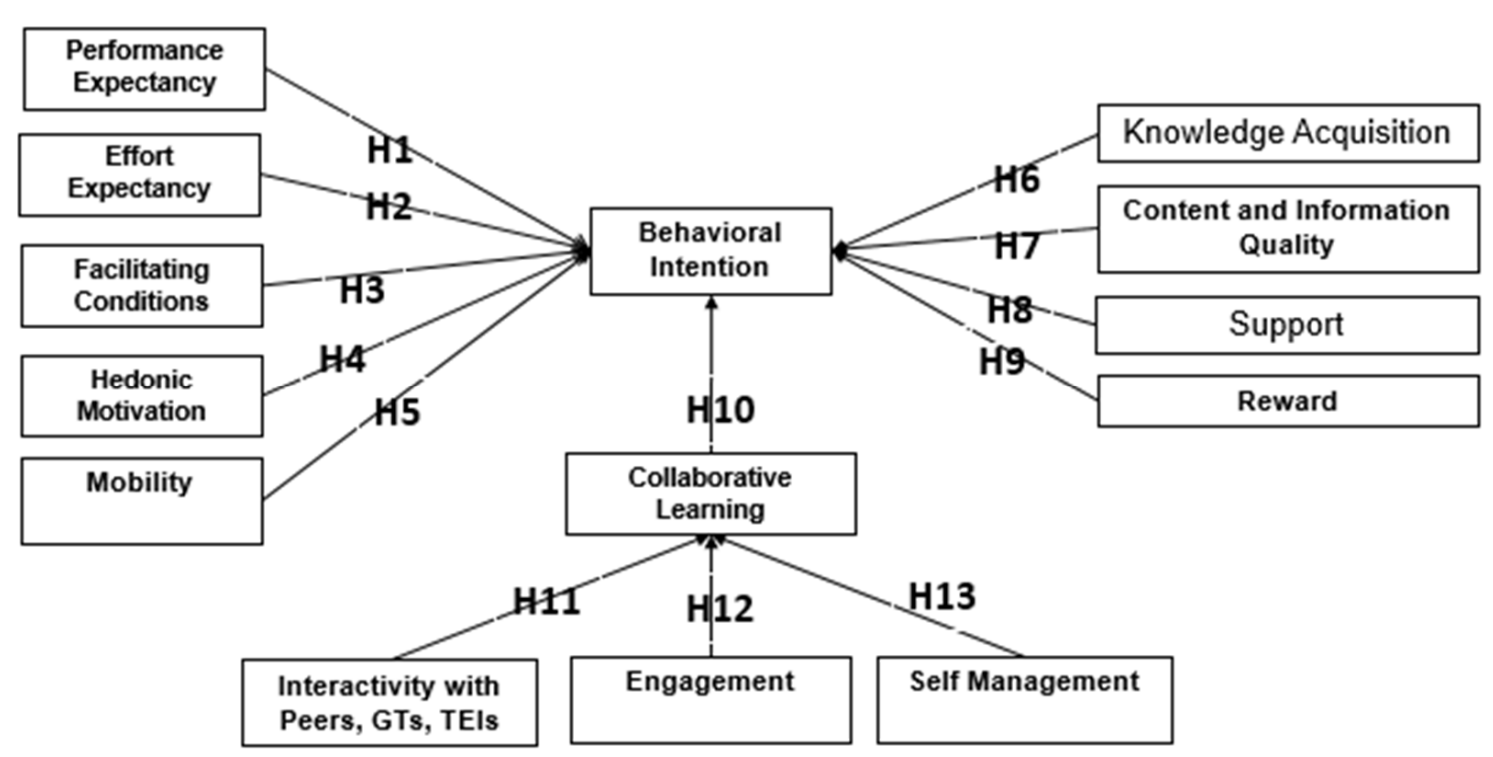

Figure 2. Proposed Research Model.

Table 1. Construct Description, proposed hypothesis, and their sources.

\begin{tabular}{lll}
\hline Construct & \multicolumn{1}{c}{ Description } & Proposed Hypothesis \\
\hline & According to [19], PE is defined as the degree & Source \\
& to which a person thinks that using an \\
& information system would improve his or \\
& her work performance. As described by \\
& Venkatesh et al. (2003), PE is the degree to \\
& which a person thinks that utilizing an \\
information system will benefit him or her in & \\
terms of work performance. & In the context of mobile collaborative \\
& learning-based CPD, PE enables the teachers \\
& to accomplish the CPD activities to improve \\
performance in terms of knowledge, skills & \\
and bringing positive change in their & \\
behavior. & \\
\hline
\end{tabular}


Table 1. Cont.

\begin{tabular}{|c|c|c|c|}
\hline Construct & Description & Proposed Hypothesis & Source \\
\hline Effort Expectancy (EE) & $\begin{array}{l}\text { The EE refers to the degree of ease associated } \\
\text { with the information system and its use [19]. } \\
\text { Venkatesh et al. (2003) define effort } \\
\text { expectancy as the ease with which people } \\
\text { believe they will be able to use an } \\
\text { information system. Because the MCL-based } \\
\text { CPD system is new and in its early stages, } \\
\text { effort expectancy is a key component with } \\
\text { the thought that an individual's acceptance is } \\
\text { dependent on the system's ease of use and } \\
\text { friendliness. Moreover, effort expectancy is } \\
\text { considered to have a greater impact on } \\
\text { behavioral intention. }\end{array}$ & H2. & [31-34] \\
\hline Facilitating Conditions (FC) & $\begin{array}{l}\text { FC refers to the degree to which a person } \\
\text { thinks that an organizational and } \\
\text { technological infrastructure exists to enable } \\
\text { usage of the system. In UTAUT2 terminology, } \\
\text { FC is considered a significant predictor to } \\
\text { assess how people utilize information } \\
\text { systems. Individual assistance, training, } \\
\text { resources to enhance skills and knowledge, } \\
\text { and access to a system are examples of } \\
\text { supporting facilities. }\end{array}$ & H3. & [31-34] \\
\hline Hedonic Motivation (HM) & $\begin{array}{l}\text { Many studies have shown that consumers } \\
\text { appreciate the technology that provides them } \\
\text { with enjoyment or pleasure while using it. } \\
\text { As a result, hedonistic motivation is } \\
\text { described as "the pleasure or satisfaction } \\
\text { derived from the use of technology". It } \\
\text { favorably influences users' intentions. }\end{array}$ & H4. & [31-33] \\
\hline Mobility (M) & $\begin{array}{l}\text { Mobility is an important feature of mobile } \\
\text { technology, defined as the use of mobile } \\
\text { devices at any time and in any location. }\end{array}$ & H5. & {$[35,36]$} \\
\hline Knowledge Acquit ion (KA) & $\begin{array}{l}\text { KA is the process of obtaining new } \\
\text { information and building on that } \\
\text { information to create new information. } \\
\text { According to several research studies, KA } \\
\text { has a favorable impact on people's } \\
\text { behavioral intentions to use technology. }\end{array}$ & H6. & [37] \\
\hline $\begin{array}{l}\text { Content and Information } \\
\text { Quality (CIQ) }\end{array}$ & $\begin{array}{l}\text { CIQ refers to the digitization of } \\
\text { lessons/topics/content for the mobile } \\
\text { learning environment. The CIQ also refers to } \\
\text { the correctness, completeness, simplicity of } \\
\text { comprehension, and relevance of course } \\
\text { materials. }\end{array}$ & H7. & {$[38,39]$} \\
\hline
\end{tabular}


Table 1. Cont.

\begin{tabular}{|c|c|c|c|}
\hline Construct & Description & Proposed Hypothesis & Source \\
\hline Support (S) & $\begin{array}{l}\text { In-service teachers get support in the form of } \\
\text { ongoing professional development, which } \\
\text { allows them to improve their subject } \\
\text { knowledge as well as their pedagogical and } \\
\text { other abilities. Mentoring, coaching, and } \\
\text { professional support at the school level are } \\
\text { examples of ongoing assistance for in-service } \\
\text { teachers. Ongoing support also refers to } \\
\text { sharing experiences, resources, and lesson } \\
\text { ideas which helps teachers to address issues } \\
\text { in their own classrooms. Ongoing support } \\
\text { has a favorable impact on teachers' } \\
\text { behavioral intentions to use MCL-based CPD } \\
\text { system. }\end{array}$ & H8. & [40] \\
\hline Reward (R) & $\begin{array}{l}\text { This construct has been added to motivate } \\
\text { and engage learners' participation in the } \\
\text { COVID-19 situation. Reward or incentive is } \\
\text { given at the end of each CPD activity to } \\
\text { improve learners' engagement to achieve } \\
\text { improved learning outcomes. According to } \\
\text { some studies, when a lesson or activity is } \\
\text { pleasant, learners are more likely to be } \\
\text { engaged and positively affect individuals' } \\
\text { behavioral intention to use technology. }\end{array}$ & H9. & {$[41,42]$} \\
\hline Collaborative Learning (CL) & $\begin{array}{l}\text { Collaboration is a collection of interactions } \\
\text { aimed at facilitating the achievement of a } \\
\text { specific goal or product by a group of people } \\
\text { working together, whether online or offline. } \\
\text { It is also a philosophy of a personal lifestyle } \\
\text { and interaction in which individuals are } \\
\text { responsible for their own actions, such as } \\
\text { learning and respecting the capabilities of } \\
\text { others. As a result, collaboration for learning } \\
\text { is an academic method to learning and } \\
\text { teaching that entails a group of learners } \\
\text { working together to solve a problem, } \\
\text { complete a task, or create a new product. }\end{array}$ & H10. & [43-45] \\
\hline
\end{tabular}


Table 1. Cont.

\begin{tabular}{|c|c|c|c|}
\hline Construct & Description & Proposed Hypothesis & Source \\
\hline $\begin{array}{l}\text { Interactivity with Peers, GTs, } \\
\text { TEIs Experts (INT) }\end{array}$ & $\begin{array}{l}\text { Traditional learning methods may disrupt } \\
\text { smooth class interactions [36]. Limited class } \\
\text { time, inflexible seating arrangements, and } \\
\text { learners' apprehensions about speaking in } \\
\text { class have all been identified as significant } \\
\text { barriers to high levels of interaction [46]. } \\
\text { Advanced technology, on the other hand, has } \\
\text { changed the way learners and teachers } \\
\text { engage in the classroom, opening new } \\
\text { avenues for interaction. Facilitating contact is } \\
\text { critical since it leads to more effective and } \\
\text { better learning. As a result, it may be a } \\
\text { critical source of educational achievement } \\
\text { [47]. This concept has previously been one of } \\
\text { the most important pedagogical problems in } \\
\text { the classroom, particularly in larger } \\
\text { classrooms and technology-related courses. } \\
\text { Learners are not only more driven to } \\
\text { comprehend when an interaction is present } \\
\text { in the learning activity, but they are also } \\
\text { more attentive, participatory, and open to } \\
\text { sharing ideas with their peers [ } 48 \text { ]. Overall, } \\
\text { the interaction has a positive impact on } \\
\text { student learning outcomes [49]. }\end{array}$ & H11. & [43-45] \\
\hline Engagement (ENG) & $\begin{array}{l}\text { Learner's engagement is a phrase that } \\
\text { describes a person's passion and excitement } \\
\text { for education as well as how that affects their } \\
\text { academic achievement and conduct [45]. } \\
\text { Learners must be engaged to acquire the } \\
\text { information and skills they will need to } \\
\text { thrive in CPD programs and in their teaching } \\
\text { career. }\end{array}$ & H12. & [43-45] \\
\hline Self-Management (SM) & $\begin{array}{l}\text { Self-management refers to the degree to } \\
\text { which a learner is self-disciplined and } \\
\text { capable of learning independently (Smith, } \\
\text { Murphy, \& Mahoney, 2003). Teachers in } \\
\text { mobile learning settings are required to have } \\
\text { self-management skills to control their } \\
\text { learning, particularly in the absence of } \\
\text { instructors and peers. }\end{array}$ & H13. & {$[46,47]$} \\
\hline Behavioral Intention (BI) & $\begin{array}{l}\text { The extent to which a person intends to carry } \\
\text { out or engage in a certain future action. It } \\
\text { refers to the participants' intention towards } \\
\text { the use of MCL-based CPD for an improved } \\
\text { professional career. }\end{array}$ & & [31-33] \\
\hline
\end{tabular}

Hypothesis 1 (H1). Performance Expectancy (PE) significantly influences the behavioral intention (BI) to use MCL for CPD purpose.

Hypothesis 2 (H2). Effort expectancy (EE) has a positive effect on behavioral intention (BI) to use $M C L$ for CPD purpose.

Hypothesis 3 (H3). Facilitating conditions (FC) significantly influences behavioral intention (BI) to use MCL for CPD purpose. 
Hypothesis 4 (H4). Hedonic motivation (HM) significantly influences behavioral intention (BI) to use MCL for CPD purpose.

Hypothesis 5 (H5). Mobility (M) significantly influences behavioral intention (BI) to use MCL for CPD purpose.

Hypothesis 6 (H6). Knowledge Acquisition (KA) significantly influences behavioral intention (BI) to use MCL for CPD purpose.

Hypothesis 7 (H7). Content and information Quality (CIQ) significantly influences behavioral intention (BI) to use MCL for CPD purpose.

Hypothesis 8 (H8). Support (S) significantly influences behavioral intention (BI) to use MCL for CPD purpose.

Hypothesis 9 (H9). Reward (R) significantly influences behavioral intention (BI) to use MCL for CPD purpose.

Hypothesis 10 (H10). Collaborative learning (CL) significantly influences behavioral intention (BI) to use MCL for CPD purpose.

Hypothesis 11 (H11). Interactivity with peers, GTs, TEIs Experts (INT) significantly influences the Collaborative learning (CL) to use MCL for CPD purpose.

Hypothesis 12 (H12). Engagement (ENG) significantly influences Collaborative learning (CL) to use MCL for CPD purpose.

Hypothesis 13 (H13). Self-management (SM) significantly influences Collaborative learning $(C L)$ to use MCL for CPD purpose.

\section{Research Methodology}

To examine the use of mobile collaborative learning in the context of the CPD of teachers, the quantitative research approach has been adopted. The data has been obtained through a questionnaire filled in by the trainees of the ongoing CPD program in Sindh, Pakistan using our enhanced theoretical model for the adoption and use of technology.

To gather the data, permission was obtained from the relevant school education directorate. The data was collected using an online Google form shared with all teachers using WhatsApp groups. The questionnaire is divided into four sections. Section 1 focuses on demography. Section 2 focuses on their past professional development experience. Section 3 focuses on how users interact with technology, and finally, in Section 4, the model's measurement elements are focused on. To conduct the study, the collection of measuring items has been derived from the previous research [31-33,37-39,41,45]. Table 2 gives the list of all the constructs, items, and their sources details. The items are evaluated on a 5-point Likert scale, with 1 indicating strongly disagree, and 5 indicating strongly agree, options. 
Table 2. Measurement constructs of the proposed model.

\begin{tabular}{ccc}
\hline Factors & No. of Items & Source \\
\hline Performance Expectancy (PE) & 04 & {$[31-33]$} \\
Effort Expectancy (EE) & 04 & {$[31-33]$} \\
Facilitation Conditions (FC) & 04 & {$[31-33]$} \\
Hedonic Motivation (HM) & 04 & {$[31-33]$} \\
Mobility (M) & 04 & {$[38,39]$} \\
Knowledge Acquisition (KA) & 03 & {$[35]$} \\
Content and Information Quality (CIQ) & 05 & {$[36,37]$} \\
Support (S) & 05 & {$[50]$} \\
Reward (R) & 04 & {$[51,52]$} \\
Collaborative learning (CL) & 04 & {$[34,53-55]$} \\
Interactivity with Peers, GTs, TEIs (INT) & 04 & {$[34,53,55]$} \\
Engagements (ENG) & 03 & {$[34,53,55]$} \\
Self-Management (SM) & 04 & {$[40,41]$} \\
Behavioral Intention (BI) & 03 & {$[31-33]$} \\
\hline
\end{tabular}

The independent constructs in the proposed model are performance expectancy (PE, four items), effort expectancy (EE, four items), facilitating conditions (FC, four items), hedonic motivation (HM, four items), mobility (M, four items), knowledge acquisition (KA, three items), content and information quality (CIQ, five items), job support (S, five items), and reward ( $\mathrm{R}$, five items). On the other hand, dependent variables include behavioral intention (BI, three items) and collaborative learning (CL, four items). There are a total of 55 measuring items, as shown in Table 2.

The data was analyzed using IBM SPSS and Structural Equation Modeling (SEMAmos). The main statistical techniques used were IBM SPSS and SEM-AMOS. The validity of the measures, the convergent validity of the measurements, and the discriminant validity of the computations are all examined [48].

\subsection{Sample Size and Data Collection}

The population of this research study included elementary school teachers in the division of Shaheed Benazirabad (SBA), Sindh, Pakistan. A total of 521 in-service Junior Elementary School Teachers (JEST) are working in three districts of the Shaheed Benazirabad division with 226 teachers in district SBA, 161 in the district Sanghar, and 134 teachers in the district of Naushahro Feroze. According to [22], an appropriate SEM analysis requires at least 150 participants; however, [49] suggests that at least 200 individuals—or at least 5 occurrences per parameter for simple SEM models-are necessary. Some studies recommend a minimal sample size of 351 participants [50]. As this study is based on 55 observable variables (items), the minimal sample size is $55 \times 5=275$. Out of 521 JEST participants, 494 teachers participated in a two-week training session using the MCL-based CPD app. Based on this, we distributed the questionnaire to teachers using WhatsApp groups during the academic year 2021-22. Following the screening of the completed questionnaires, a total of 472 correctly completed questionnaires were selected for analysis. Others were ruled out owing to missing or incomplete data.

\subsection{Piloting of Research Tool}

A pilot test on 75 teachers was conducted before the main analysis to ensure that the questionnaire is reliable. Cronbach's alpha method was used to check for data consistency. According to [51], Cronbach's alpha value should be higher than 0.7. Cronbach's alpha values for all the constructs are more than 0.7. As a result, the data was utilized for SEM analysis. 


\section{Results and Analysis}

\subsection{Demographic Data Analysis}

The sample data collected for experimental analysis include 304 (64.4\%) male and $168(35.5 \%)$ female participants. As per the age groups of teachers, $325(68.9 \%)$ are aged 31-40 years, $23(4.9 \%)$ are aged $41-50$ years, and $124(26.3 \%)$ are aged $20-30$ years. As per the qualification of the participants, 99 (21\%) out of 472 hold bachelor's degrees, and $368(78.0 \%)$ hold Master's/MPhil qualifications. Other than academic qualification, 164 (34.7\%) have a B.Ed. professional degree, 298 (63.1\%) teachers have an M.Ed. qualification, and $6(1.3 \%)$ teachers have an associate degree in education. Based on the duration of the teaching experience, $230(48.7 \%)$ have a teaching experience of $1-5$ years and $174(36.9)$ have more than 10 years of teaching experience. It is also important to mention that 449 (95.1\%) teachers/respondents have already participated in 1-5 CPD training using conventional methods. Table 3 gives details of the demographic information in a nutshell.

Table 3. Descriptive analysis.

\begin{tabular}{cccc}
\hline \multirow{2}{*}{ Items } & Description & Sample & \% \\
\hline \multirow{2}{*}{ Gender } & Male & 304 & 64.4 \\
& Female & 168 & 35.6 \\
\hline \multirow{2}{*}{ Age } & $20-30$ & 124 & 26.3 \\
& $31-40$ & 325 & 68.9 \\
& $41-50$ & 23 & 4.9 \\
& $51-60$ & 0 & 0 \\
\hline \multirow{3}{*}{ Education (Academic) } & 99 & 21.0 \\
& Bachelor's degree & 368 & 78.0 \\
& Masters/M.Phil. & 3 & 0.6 \\
& Ph.D. & 2 & 0.4 \\
\hline \multirow{3}{*}{ Professional } & Other & 164 & 34.7 \\
& B.Ed. & 298 & 63.1 \\
& M.Ed. & 6 & 1.3 \\
& ADE & 4 & 0.8 \\
\hline \multirow{2}{*}{ Teaching Experience } & Other & 230 & 48.7 \\
& $1-5$ & 174 & 36.9 \\
& $6-10$ & 68 & 14.4 \\
\hline \multirow{2}{*}{ No. of CPD training } & $11-20$ & 449 & 95.1 \\
received & $1-5$ & 23 & 4.9 \\
& $6-10$ & 0 & 0.0 \\
\hline \multirow{2}{*}{} & $11-20$ & & \\
& & &
\end{tabular}

\subsection{Previous $C P D$ Experience}

As shown in Table 4, 378 (80.1\%) respondents have never received ongoing support during their teaching job, whereas 3\% to $16.3 \%$ have received CPD assistance previously. The second question is related to the CPD training support during the induction period. To answer that question, $221(46.2 \%)$ respondents replied in negation. Regarding the duration of CPD participation in the past, 361 (76.5\%) respondents replied that they have attended two weeks of CPD training. Regarding the mode of CPD training, 375 (79.5\%) participants have had experience in face-to-face CPD training, while just 13\% of teachers had previously participated in online training workshops. Relating to the CPD training organized by government and private institutes in Sindh, $460(96 \%)$ attended CPD training organized by PITE whereas $4 \%$ of the teachers attended CPDs organized by other non-governmental organizations in Sindh. 
Table 4. Descriptive analysis.

\begin{tabular}{|c|c|c|c|}
\hline Questions & Description & Sample & Percentage $(\%)$ \\
\hline \multirow{3}{*}{$\begin{array}{l}\text { Q: (1) Do you receive any support } \\
\text { (practical or on-demand CPD) }\end{array}$} & Yes & 77 & 16.3 \\
\hline & No & 378 & 80.1 \\
\hline & Maybe & 17 & 3.6 \\
\hline \multirow{3}{*}{$\begin{array}{l}\text { Q: (2) Did you receive face-to-face } \\
\text { or practical CPD during your } \\
\text { induction period? }\end{array}$} & Yes & 240 & 50.8 \\
\hline & No & 221 & 46.8 \\
\hline & No Response & 11 & 2.3 \\
\hline \multirow{5}{*}{$\begin{array}{l}\text { Q: (3) What was the } \\
\text { length/duration of CPD you } \\
\text { received in the past? (Please select } \\
\text { only one answer) }\end{array}$} & $2-3 \mathrm{~h}$ & 44 & 9.3 \\
\hline & 1-2 Days & 11 & 2.3 \\
\hline & 3-5 Days & 15 & 3.2 \\
\hline & 1 Week & 41 & 8.7 \\
\hline & 2 Week & 361 & 76.5 \\
\hline \multirow{5}{*}{$\begin{array}{l}\text { Q: (6) What was the mode of } \\
\text { delivery of the CPD you received in } \\
\text { the past? (Tick more than one } \\
\text { answer) }\end{array}$} & Face-to-Face (FTF) & 375 & 79.4 \\
\hline & Mobile Based CPD & 30 & 12.7 \\
\hline & A combination of FTF and Online & 37 & 6.3 \\
\hline & Collaborative learning Mode & 24 & 5.0 \\
\hline & Don't Know & 6 & 1.3 \\
\hline \multirow{3}{*}{$\begin{array}{l}\text { Q: (7) Which entity/training } \\
\text { institute provided you with the } \\
\text { training you attended? }\end{array}$} & PITE/NGO & 460 & 97.5 \\
\hline & RSU & 11 & 2.3 \\
\hline & Don't Know & 1 & 0.2 \\
\hline
\end{tabular}

\subsection{About Technology Usage}

The participants were also assessed on the use of the technology in the past. The participants were asked whether they own a smartphone. To answer that, $462(98 \%)$ replied positively. Relating to the previous experience on the use of mobile collaborative learning, 469 (99\%) participants never utilized mobile technology for professional development at the workplace to enhance classroom instruction. When asked about the pleasure with the current professional development mode, $332(70.3 \%)$ showed dissatisfaction with the current traditional CPD training. The participants were also asked about the amount of time they spend on the use of the mobile phone in a day; replying to that, $175(37.1 \%)$ participants surf for 2 to $3 \mathrm{~h}$ in a day, while $133(28.2 \%)$ of teachers used mobile phones for more than $3 \mathrm{~h}$ daily. Regarding the access to the Internet in the districts of their residence, $422(89.4 \%)$ teachers said they have access to the Internet, and $288(61 \%)$ teachers utilize the cellular network on their mobile devices, while the other teachers were using DSL, Fiber, or Broadband (Evo). Moreover, 375 out of 472 teachers have access to $4 \mathrm{G}$ internet through their mobile devices. Teachers report that they receive little assistance at their schools, but 447 (98.7\%) teachers said that if CPD training is made accessible via mobile technology, they would attempt to utilize mobile technology for professional development. Table 5 gives description, sample, and percentage of participant responses.

\subsection{Reliability Analysis}

The convergent and discriminant validity of the constructs has been evaluated using SEM [52-54]. In the initial phase, composite reliability (CR), average variance extracted (AVE), Cronbach's alpha, and factor loading were evaluated as suggested in [51]. As suggested in [55], CR and AVE values should be equal to or greater than 0.8 and 0.5, respectively. Moreover, according to [51], the Cronbach's Alpha should be above 0.7 to be considered highly trustworthy. The CR test findings in this research are greater than 0.80 , which is deemed acceptable while also being supportive. The majority of the AVE values in the measurement model test are between 0.65 and 0.85 , which is regarded as very trustworthy. Moreover, Cronbach's alpha values for all the constructs are greater than 0.7 . The findings for CR, AVE, and Cronbach's alpha are shown in Table 6. 
Table 5. Descriptive analysis.

\begin{tabular}{|c|c|c|c|}
\hline Questions & Description & Sample & $\%$ \\
\hline \multirow{2}{*}{$\begin{array}{l}\text { Have you ever used Mobile collaborative learning technology for } \\
\text { your PD to improve classroom teaching at school? }\end{array}$} & Yes & 3 & 0.6 \\
\hline & No & 469 & 99.3 \\
\hline \multirow{2}{*}{ Do you possess a smartphone? } & Yes & 462 & 97.9 \\
\hline & No & 10 & 2.1 \\
\hline \multirow{6}{*}{ How satisfied are you with the existing traditional PD received? } & Highly Satisfied & 6 & 1.2 \\
\hline & Moderately Satisfied & 5 & 1.0 \\
\hline & Somehow satisfied & 3 & 0.6 \\
\hline & Satisfied & 123 & 26.1 \\
\hline & Not satisfied at all & 332 & 70.3 \\
\hline & Don't Know & 3 & 0.6 \\
\hline \multirow{5}{*}{$\begin{array}{l}\text { If you have a mobile, then how much time do you spend on your } \\
\text { mobile phone on average in a day }\end{array}$} & Less than $30 \mathrm{~min}$ & 6 & 1.3 \\
\hline & From $30 \mathrm{~min}$ to $1 \mathrm{~h}$ & 40 & 8.5 \\
\hline & from $1 \mathrm{~h}$ to $2 \mathrm{~h}$ & 118 & 25.0 \\
\hline & from $2 \mathrm{~h}$ to $3 \mathrm{~h}$ & 175 & 37.1 \\
\hline & more than $3 \mathrm{~h}$ & 133 & 28.2 \\
\hline \multirow{2}{*}{ Do you think Internet access is easy on mobile in your area? } & Yes & 422 & 89.4 \\
\hline & No & 50 & 10.5 \\
\hline \multirow{2}{*}{$\begin{array}{l}\text { If CPD is available for you through a mobile device, you will try to } \\
\text { use mobile technology for your professional development }\end{array}$} & Yes & 466 & 98.7 \\
\hline & No & 6 & 1.3 \\
\hline \multirow{4}{*}{ Which of the following Internet connection do you have at home? } & Broadband & 67 & 14.2 \\
\hline & Cellular & 288 & 61.0 \\
\hline & DSL & 84 & 17.8 \\
\hline & Fiber & 33 & 7.0 \\
\hline \multirow{5}{*}{$\begin{array}{l}\text { Which type of the following internet access do you have on your } \\
\text { mobile phone? }\end{array}$} & $2 \mathrm{G}$ & 17 & 3.6 \\
\hline & $3 G$ & 78 & 16.5 \\
\hline & $4 \mathrm{G}$ & 375 & 79.5 \\
\hline & $5 \mathrm{G}$ & 0 & 0 \\
\hline & Don't Have & 2 & 0.4 \\
\hline \multirow{2}{*}{ Do you receive on-the-job support during and after CPD training? } & Yes & 5 & 1.05 \\
\hline & No & 467 & 98.9 \\
\hline
\end{tabular}

Table 6. Construct CR, AVE, and Reliability Analysis.

\begin{tabular}{cccc}
\hline & CR & Average Variance Extracted & Cronbach's Alpha \\
\hline Performance Expectancy (PE) & 0.910 & 0.767 & 0.897 \\
Effort Expectancy (EE) & 0.837 & 0.661 & 0.856 \\
Facilitation Conditions (FC) & 0.825 & 0.645 & 0.845 \\
Hedonic Motivation (HM) & 0.913 & 0.773 & 0.903 \\
Mobility (M) & 0.952 & 0.853 & 0.955 \\
Knowledge Acquisition (KA) & 0.867 & 0.745 & 0.872 \\
Content and Information Quality (CIQ) & 0.926 & 0.765 & 0.933 \\
Support (S) & 0.818 & 0.670 & 0.862 \\
Reward (R) & 0.892 & 0.736 & 0.884 \\
Collaborative learning (CL) & 0.886 & 0.727 & 0.919 \\
Interactivity with Peers, GTs, TEIs (INT) & 0.929 & 0.804 & 0.944 \\
Engagements for learning (ENG) & 0.835 & 0.706 & 0.822 \\
Self-Management (SM) & 0.835 & 0.658 & 0.849 \\
Behavioral Intention (BI) & 0.809 & 0.676 & 0.905 \\
\hline
\end{tabular}

For the factor loading, the research studies in [51,55] suggest that an appropriate factor loading for subsequent analysis should be more than 0.5 . Following the findings of the present research investigation, as shown in Table 7, all factors have values greater than 0.7. 
Table 7. Measurement of Factor Loading.

\begin{tabular}{|c|c|c|c|}
\hline Construct & Item Code & Item & Factor Loading \\
\hline \multirow{4}{*}{ Performance Expectancy (PE) } & PE1 & is useful to perform my activities & 0.815 \\
\hline & PE2 & enables me to accomplish my tasks more quickly & 0.924 \\
\hline & PE3 & improves my job performance & 0.930 \\
\hline & PE4 & increases my learning outcomes & 0.827 \\
\hline \multirow{4}{*}{ Effort Expectancy (EE) } & EE1 & $\begin{array}{l}\text { My interaction with the MCL-based CPD system } \\
\text { is clear and understandable. }\end{array}$ & 0.809 \\
\hline & EE2 & $\begin{array}{l}\text { It would be easy for me to become skillful at } \\
\text { using the MCL-based CPD system. }\end{array}$ & 0.799 \\
\hline & EE4 & I would find the system easy to use. & 0.818 \\
\hline & EE4 & Learning to operate the system is easy for me. & 0.825 \\
\hline \multirow{4}{*}{ Facilitating Conditions (FC) } & FC1 & I have the necessary resources & 0.807 \\
\hline & FC2 & I have the necessary knowledge. & 0.803 \\
\hline & FC3 & $\begin{array}{l}\text { It does not require compatibility with other } \\
\text { systems I use. }\end{array}$ & 0.823 \\
\hline & FC4 & $\begin{array}{l}\text { A specific person (or group) is available for } \\
\text { assistance with system difficulties. }\end{array}$ & 0.780 \\
\hline \multirow{4}{*}{ Hedonic Motivation (HM) } & HM1 & Fun & 0.859 \\
\hline & HM2 & enjoyable & 0.923 \\
\hline & HM3 & Entertaining & 0.923 \\
\hline & HM4 & motivation towards learning & 0.807 \\
\hline \multirow{4}{*}{ Mobility (M) } & M1 & $\begin{array}{l}\text { I know that mobile devices are the mediums for } \\
\text { my CPD }\end{array}$ & 0.927 \\
\hline & M2 & $\begin{array}{l}\text { It is convenient to access CPD activity anywhere } \\
\text { at any time }\end{array}$ & 0.930 \\
\hline & M3 & $\begin{array}{c}\text { Mobility makes it possible to get the real-time } \\
\text { support }\end{array}$ & 0.939 \\
\hline & M4 & $\begin{array}{l}\text { Mobility is an outstanding advantage of } \\
\text { mobile-based CPD }\end{array}$ & 0.899 \\
\hline \multirow{3}{*}{ Knowledge Acquisition (KA) } & KA1 & $\begin{array}{l}\text { Using MCL system for my CPD, I acquire new } \\
\text { knowledge through training and on-job support }\end{array}$ & 0.853 \\
\hline & KA2 & $\begin{array}{l}\text { Using the MCL system for my professional } \\
\text { development, I acquire new skills (new methods, } \\
\text { new teaching techniques, assessment techniques, } \\
\text { and lesson planning, research skills) }\end{array}$ & 0.879 \\
\hline & KA3 & $\begin{array}{l}\text { Through the MCL based CPD I come up with } \\
\text { innovative ideas, learn new things and the latest } \\
\text { trends and techniques }\end{array}$ & 0.856 \\
\hline
\end{tabular}


Table 7. Cont.

\begin{tabular}{|c|c|c|c|}
\hline Construct & Item Code & Item & Factor Loading \\
\hline \multirow{5}{*}{$\begin{array}{l}\text { Content and Information } \\
\text { Quality (Q) }\end{array}$} & CIQ1 & $\begin{array}{l}\text { MCL System provides information that is } \\
\text { relevant to my needs. }\end{array}$ & 0.853 \\
\hline & CIQ2 & $\begin{array}{l}\text { MCL System provides comprehensive } \\
\text { information that is easy to understand. }\end{array}$ & 0.879 \\
\hline & CIQ3 & $\begin{array}{l}\text { MCL System provides information that is exactly } \\
\text { what I want. }\end{array}$ & 0.899 \\
\hline & CIQ4 & $\begin{array}{l}\text { MCL System provides me with organized } \\
\text { content and information. }\end{array}$ & 0.882 \\
\hline & CIQ5 & $\begin{array}{l}\text { MCL System provides up-to-date content and } \\
\text { information. }\end{array}$ & 0.859 \\
\hline \multirow{5}{*}{ Support (S) } & S1 & $\begin{array}{l}\text { Using MCL, I always get on-job support from } \\
\text { experts }\end{array}$ & 0.739 \\
\hline & S2 & $\begin{array}{l}\text { MCL system facilitates me to resolve ongoing job } \\
\text { issues related to pedagogy, assessment, and } \\
\text { content. }\end{array}$ & 0.790 \\
\hline & S3 & $\begin{array}{l}\text { MCL system support and facilitation at the } \\
\text { school level were interesting for me. Solves all } \\
\text { my classroom issues. }\end{array}$ & 0.825 \\
\hline & S4 & $\begin{array}{l}\text { The facilities provided by MCL System help me } \\
\text { to practice the new methods I've learned. }\end{array}$ & 0.793 \\
\hline & S5 & $\begin{array}{l}\text { The system helps and feedback is very } \\
\text { supportive }\end{array}$ & 0.723 \\
\hline \multirow{4}{*}{ Reward (R) } & $\mathrm{R} 1$ & $\begin{array}{l}\text { CPD Rewards motivates me to increase my } \\
\text { performance. }\end{array}$ & 0.810 \\
\hline & $\mathrm{R} 2$ & $\begin{array}{l}\text { I am happy with the recognition and rewards for } \\
\text { my outstanding work and contribution. }\end{array}$ & 0.904 \\
\hline & $\mathrm{R} 3$ & The work I do is appreciated. & 0.895 \\
\hline & $\mathrm{R} 4$ & $\begin{array}{l}\text { The reward system has increased the level of } \\
\text { competition among teachers }\end{array}$ & 0.819 \\
\hline \multirow{4}{*}{ Collaborative learning (CL) } & CL1 & $\begin{array}{l}\text { I felt that using MCL based CPD system for } \\
\text { collaborative learning was effective }\end{array}$ & 0.839 \\
\hline & CL2 & $\begin{array}{c}\text { I was able to develop pedagogical content } \\
\text { knowledge and skills through peer } \\
\text { collaborations }\end{array}$ & 0.872 \\
\hline & CL3 & $\begin{array}{l}\text { I was able to develop new skills and knowledge } \\
\text { from the other members (GTs \& TEIs Experts) }\end{array}$ & 0.858 \\
\hline & CL4 & $\begin{array}{l}\text { The collaborative learning experience in the } \\
\text { MCL based CPD environment is better than a } \\
\text { face-to-face learning environment }\end{array}$ & 0.842 \\
\hline \multirow{4}{*}{$\begin{array}{c}\text { Interactivity with Peers, GTs, } \\
\text { TEIs (INT) }\end{array}$} & INT1 & $\begin{array}{l}\text { Using MCL system facilitates interaction with } \\
\text { peers, GTs, TEIs }\end{array}$ & 0.841 \\
\hline & INT2 & $\begin{array}{l}\text { Using MCL system allows discussion with peers, } \\
\text { GTs, TEIs }\end{array}$ & 0.888 \\
\hline & INT3 & $\begin{array}{l}\text { Using MCL system facilitate to share problems \& } \\
\text { resources with peers, GTs, TEIs }\end{array}$ & 0.911 \\
\hline & INT4 & $\begin{array}{l}\text { Using MCL system allows the exchange of } \\
\text { information with peers, GTs, TEIs }\end{array}$ & 0.942 \\
\hline
\end{tabular}


Table 7. Cont.

\begin{tabular}{|c|c|c|c|}
\hline Construct & Item Code & Item & Factor Loading \\
\hline \multirow{3}{*}{ Engagements (ENG) } & ENG1 & $\begin{array}{l}\text { By using the MCL, the system gives me a chance } \\
\text { to build my relationship with my Peers, GTs, } \\
\text { Experts/Mentors }\end{array}$ & 0.838 \\
\hline & ENG2 & $\begin{array}{l}\text { By using the system, I find it valuable to interact } \\
\text { with peers, GTs, TEIs experts }\end{array}$ & 0.849 \\
\hline & ENG3 & $\begin{array}{l}\text { By using the MCL system I felt that my opinions } \\
\text { are considered }\end{array}$ & 0.833 \\
\hline \multirow{4}{*}{ Self-Management (SM) } & SM1 & $\begin{array}{l}\text { I am a self-disciplined learner while performing } \\
\text { my CPD activities }\end{array}$ & 0.822 \\
\hline & SM2 & $\begin{array}{l}\text { I can complete my CPD activities in a timely } \\
\text { manner }\end{array}$ & 0.866 \\
\hline & SM3 & $\begin{array}{l}\text { In my study, I set goals and have a high degree } \\
\text { of initiative }\end{array}$ & 0.822 \\
\hline & SM4 & I am organized in performing my CPD activities & 0.729 \\
\hline \multirow{3}{*}{ Behavioral Intention (BI) } & BI1 & $\begin{array}{l}\text { I intend to use the system in the future to } \\
\text { improve my teaching effectiveness }\end{array}$ & 0.829 \\
\hline & BI2 & $\begin{array}{c}\text { I always try to use the system for my CPD } \\
\text { activities }\end{array}$ & 0.822 \\
\hline & BI3 & $\begin{array}{l}\text { I plan to use the system continuously in my } \\
\text { teaching career for CPD }\end{array}$ & 0.816 \\
\hline
\end{tabular}

The measurement of discriminate validity is described as a variance (or covariance) difference between the factors. The correlation coefficients for all the variables are shown in Table 8. The diagonal values (in bold) are the square root of AVE and are greater than their respective correlation coefficients. Since these results have been established, the concept level discriminant validity has been verified. As shown in Table 8, as the AVE's square root of every concept surpassed their inter-construct correlation estimations, the discriminant is validated $[51,53,54]$.

Table 8. Discriminated Validity Measures.

\begin{tabular}{|c|c|c|c|c|c|c|c|c|c|c|c|c|c|c|}
\hline & PE & $\mathrm{EE}$ & HM & FC & INT & ENG & CL & KA & CIQ & $S$ & SM & $\mathbf{M}$ & $\mathbf{R}$ & BI \\
\hline PE & 0.876 & & & & & & & & & & & & & \\
\hline $\mathrm{EE}$ & 0.017 & 0.813 & & & & & & & & & & & & \\
\hline $\mathrm{HM}$ & 0.065 & -0.007 & 0.879 & & & & & & & & & & & \\
\hline $\mathrm{FC}$ & 0.077 & 0.185 & 0.048 & 0.803 & & & & & & & & & & \\
\hline INT & -0.005 & 0.137 & 0.013 & 0.167 & 0.897 & & & & & & & & & \\
\hline ENG & 0.006 & 0.062 & 0.060 & 0.065 & 0.088 & 0.840 & & & & & & & & \\
\hline $\mathrm{CL}$ & -0.018 & 0.279 & -0.022 & 0.226 & 0.285 & 0.285 & 0.853 & & & & & & & \\
\hline KA & 0.057 & 0.090 & 0.128 & 0.095 & -0.025 & 0.062 & -0.014 & 0.863 & & & & & & \\
\hline CIQ & 0.078 & 0.060 & -0.011 & 0.156 & 0.109 & 0.017 & 0.101 & 0.014 & 0.875 & & & & & \\
\hline$S$ & 0.035 & 0.225 & 0.031 & 0.232 & 0.235 & 0.124 & 0.291 & 0.031 & 0.254 & 0.775 & & & & \\
\hline SM & 0.031 & 0.157 & -0.010 & 0.092 & 0.325 & 0.081 & 0.181 & -0.068 & 0.046 & 0.155 & 0.811 & & & \\
\hline M & 0.060 & 0.020 & 0.052 & 0.008 & 0.001 & 0.023 & -0.012 & 0.346 & 0.126 & 0.012 & 0.068 & 0.924 & & \\
\hline $\mathrm{R}$ & -0.055 & 0.067 & 0.033 & -0.008 & 0.046 & 0.100 & 0.033 & 0.020 & 0.012 & 0.120 & 0.059 & -0.004 & 0.858 & \\
\hline $\mathrm{BI}$ & 0.107 & 0.373 & -0.022 & 0.374 & 0.142 & 0.216 & 0.349 & 0.095 & 0.268 & 0.330 & 0.154 & -0.038 & 0.114 & 0.822 \\
\hline
\end{tabular}


Hair et al. [55] recommended that the model assessment should be measured through the highest likelihood estimation process by goodness-of-fit techniques. Table 9 shows goodness-of-fit values for the assessment of the model. Based on the obtained value of $\chi^{2}$ (2196), the degree of freedom (df) (1403), the ratio of $\chi^{2} / \mathrm{df}$ (1.565), and GFI ("Goodness of fit index") (0.856), the resulting RMSEA ("Root mean square error of approximation") value is 0.035 . The obtained value of the NFI ("Normed fit index") and CFI ("Comparative fit index") are 0.886 and 0.955 , respectively. The "Adjusted goodness of fit index" (AGFI) measure yields an achieved value of 0.842 . Table 9 makes it abundantly apparent that the research methodology suggested in the current study effectively accommodates the collected data.

Table 9. Measurement of goodness-of-fit.

\begin{tabular}{cccc}
\hline Measures & Fit Indices & Obtained Value & Recommended Criteria \\
\hline & $\chi^{2}$ & 2196 & - \\
Absolute fit measures & $\mathrm{df}$ & 1403 & - \\
& $\chi^{2} / \mathrm{df}$ & 1.565 & $1<\chi^{2} / \mathrm{df}<3$ \\
& GFI & 0.856 & $\geq 0.90$ \\
& RMSEA & 0.35 & $\geq 0.05$ \\
\hline \multirow{2}{*}{ Incremental fit measures } & NFI & 0.886 & $\geq 0.90$ \\
& CFI & 0.955 & $\geq 0.90$ \\
\hline Parsimony fit measures & AGFI & 0.842 & \\
\hline
\end{tabular}

In this case, the structural model is utilized to investigate the relationship between the suggested hypotheses of exogenous and endogenous variables. It is a way of investigating whether the constructs in the proposed theoretical framework influence each other. The path analysis has been performed to analyze the assumptions that are presented in the developed model. The hypotheses are tested, and the findings are shown in Table 10. The study results reveal that all 13 hypotheses $(\mathrm{H} 1, \mathrm{PE} \rightarrow \mathrm{BI}),(\mathrm{H} 2, \mathrm{EE} \rightarrow \mathrm{BI}),(\mathrm{H} 3, \mathrm{FC} \rightarrow \mathrm{BI})$, $(\mathrm{H} 4, \mathrm{HM} \rightarrow \mathrm{BI}),(\mathrm{H} 5, \mathrm{M} \rightarrow \mathrm{BI}),(\mathrm{H} 6, \mathrm{KA} \rightarrow \mathrm{BI}),(\mathrm{H} 7, \mathrm{CIQ} \rightarrow \mathrm{BI}),(\mathrm{H} 8, \mathrm{~S} \rightarrow \mathrm{BI}),(\mathrm{H} 9, \mathrm{R} \rightarrow \mathrm{BI}),(\mathrm{H} 10$, $\mathrm{CL} \rightarrow \mathrm{BI}),(\mathrm{H} 11, \mathrm{INT} \rightarrow \mathrm{CL}),(\mathrm{H} 12, \mathrm{ENG} \rightarrow \mathrm{CL})$, and $(\mathrm{H} 13, \mathrm{SM} \rightarrow \mathrm{CL})$ are accepted. All the hypotheses are statistically significant $(p<0.05$ or $p<0.001)$ and therefore are supported by the data.

Table 10. Instrument measurement items and source of adoption.

\begin{tabular}{|c|c|c|c|c|c|c|c|c|}
\hline Hypothesis & & Relationship & & $\begin{array}{l}\text { Estimates } \\
(\beta, \text { Value) }\end{array}$ & $\begin{array}{c}\text { S.E. } \\
(t, \text { Value })\end{array}$ & $\begin{array}{c}\text { C.R. } \\
(p, \text { Value })\end{array}$ & Supported & Result \\
\hline $\mathrm{H} 1$ & $\mathrm{PE}$ & $\rightarrow$ & $\mathrm{BI}$ & 0.124 & 0.061 & 2.013 & Yes ** & Accepted \\
\hline $\mathrm{H} 2$ & $\mathrm{EE}$ & $\rightarrow$ & $\mathrm{BI}$ & 0.255 & 0.047 & 5.385 & Yes *** & Accepted \\
\hline H3 & FC & $\rightarrow$ & $\mathrm{BI}$ & 2.326 & 0.393 & 5.921 & Yes *** & Accepted \\
\hline $\mathrm{H} 4$ & $\mathrm{HM}$ & $\rightarrow$ & BI & -0.134 & 0.061 & -2.195 & Yes ** & Accepted \\
\hline $\mathrm{H} 4$ & $\mathrm{M}$ & $\rightarrow$ & $\mathrm{BI}$ & -0.11 & 0.044 & -2.497 & Yes ** & Accepted \\
\hline H6 & $\mathrm{KA}$ & $\rightarrow$ & $\mathrm{BI}$ & 0.109 & 0.052 & 2.083 & Yes ** & Accepted \\
\hline $\mathrm{H} 7$ & CIQ & $\rightarrow$ & $\mathrm{BI}$ & 0.357 & 0.097 & 3.668 & Yes *** & Accepted \\
\hline $\mathrm{H} 8$ & $S$ & $\rightarrow$ & BI & 0.137 & 0.059 & 2.334 & Yes ** & Accepted \\
\hline $\mathrm{H} 9$ & $\mathrm{R}$ & $\rightarrow$ & BI & 0.128 & 0.065 & 1.966 & Yes ${ }^{* *}$ & Accepted \\
\hline $\mathrm{H} 10$ & CL & $\rightarrow$ & BI & 0.205 & 0.051 & 4.006 & Yes *** & Accepted \\
\hline H11 & INT & $\rightarrow$ & CL & 0.235 & 0.052 & 4.55 & Yes *** & Accepted \\
\hline $\mathrm{H} 12$ & ENG & $\rightarrow$ & $\mathrm{CL}$ & 3.991 & 0.744 & 5.367 & Yes *** & Accepted \\
\hline $\mathrm{H} 13$ & SM & $\rightarrow$ & $\mathrm{CL}$ & 0.08 & 0.04 & 2.001 & Yes ** & Accepted \\
\hline
\end{tabular}


The findings of the study reveal that performance expectancy (PE) has a statistically significant effect on teachers' behavioral intention (BI) $(\beta=0.124, p<0.05)$, thereby supporting the hypothesis $(\mathrm{H} 1, \mathrm{PE} \rightarrow \mathrm{BI})$. The effort expectancy (EE) and facilitating conditions (FC) were also found to have statically significant effects on teachers' behavioral intentions, with (BI) $(\beta=0.255, p<0.001)$ and $(\beta=2.326, p<0.001)$, respectively, thereby supporting the hypothesis $(\mathrm{H} 2, \mathrm{EE} \rightarrow \mathrm{BI}),(\mathrm{H} 3, \mathrm{FC} \rightarrow \mathrm{BI})$. The finding also showed that hedonic motivation (HM) and mobility $(\mathrm{M})$ has a significant impact on teachers behavioral intention, with (BI) $(\beta=-0.134, p<0.05)$, and $(\beta=-0.11, p<0.05)$, respectively, which is consistent with the hypothesis $(\mathrm{H} 4, \mathrm{HM} \rightarrow \mathrm{BI}),(\mathrm{H} 5, \mathrm{M} \rightarrow \mathrm{BI})$. Moreover, the variables, knowledge acquisition (KA), content and information quality (CIQ), support (S), and reward (R) also have a statistically significant impact on behavioral intentions with values $(\beta=0.109, p<0.05)$, $(\beta=0.357, p<0.001),(\beta=0.137, p<0.05)$, and $(\beta=0.128, p<0.05)$, respectively. As a result $(\mathrm{H} 6, \mathrm{KA} \rightarrow \mathrm{BI}),(\mathrm{H} 7, \mathrm{CIQ} \rightarrow \mathrm{BI}),(\mathrm{H} 8, \mathrm{~S} \rightarrow \mathrm{BI}),(\mathrm{H} 9, \mathrm{R} \rightarrow \mathrm{BI})$, are supported.

Furthermore, three exogenous factors were shown to be significantly associated with collaborative learning (CL): interactivity with peers, TEI experts (INT) $(\beta=0.235, p<0.001)$, engagement $(\mathrm{ENG})(\beta=0.3 .991, p<0.001)$, and self-management $(\mathrm{SM})(\beta=0.08, p<0.05)$, which support hypothesis (H11, INT $\rightarrow$ CL), (H12, ENG $\rightarrow$ CL), and (H13, SM $\rightarrow$ CL), respectively. In the end, the impact of collaborative learning (CL) on behavioral intention (BI) was also resulted statistically significant $(\mathrm{BI})(\beta=0.205, p<0.001)$, supporting the hypothesis $(\mathrm{H} 10, \mathrm{CL} \rightarrow \mathrm{BI})$.

\section{Discussion and Conclusions}

Teachers' professional development plays a key role in the sustainable development of teachers' careers and imparting quality education. Many institutions at the government and non-government level are striving hard to devise new policies enriched with state-ofthe-art tools and techniques to strengthen professional development programs. However, the teaching and learning process is on the verge of devastation, where educational systems are weak and lack the availability of basic facilities such as trained and skilled teachers and lack of the integration of the latest teaching (and learning) trends. The recent COVID-19 pandemic has further escalated the situation and has badly affected the motivation, interest, and engagement of teachers and students. This study extends the existing CPD model used for the professional development of in-service teachers in the province of Sindh, Pakistan. The extensions are based on the integration of mobile technology for collaborative learning and providing on-the-job support to teacher educators. To achieve the goals, an online mobile app has been designed to provide support to teachers, GTs, and TEIs to meet, discuss, and share context information anywhere and anytime to improve teaching and learning performances efficiently and cost-effectively. Though the use of mobile technology in various fields has received much attention, its usage and implementation have been challenging issues in the context of the CPD of teachers. To the best of our knowledge, none of the previous studies have focused on the acceptance of the use of mobile technology for the professional development of teachers, particularly in Sindh, Pakistan.

To assess and analyze the use and acceptance of mobile technology for teachers' education, this study extends UTAUT2 model by incorporating new constructs including CPD (Knowledge Acquisition, Content and Information Quality, Support, and Reward), mobile technology (Mobility), and collaborative learning (Collaborative learning and Interactivity with Peers, Experts, Engagement, and Self-Management). The significant factors from the educational and training point of view are derived from an elaborated literature review for a better understanding of mobile usage and collaborative learning constructs and the relationship between them.

For the experimental results, data was analyzed using IBM SPSS and Structural Equation Modeling (SEM-AMOS). The validity of the measures, the convergent validity of the measurements, and the discriminant validity of the computations are all examined.

The population of this research study included elementary school teachers in the division of Shaheed Benazirabad (SBA), Sindh, Pakistan. Out of 521 JEST participants, 
494 teachers participated in a two-week training session using the MCL-based CPD app. Based on this, we distributed the questionnaire to teachers using WhatsApp groups during the academic year 2021-22. Following the screening of the completed questionnaires, a total of 472 correctly completed questionnaires were selected for analysis.

In total 14 constructs have been adopted, and 13 hypotheses with 55 measuring items have been created. According to the findings, the Performance Expectancy (PE) has a statistically significant effect on teachers' behavioral intention $(\beta=0.124, p<0.05)$, and thus supports the hypothesis $(\mathrm{H} 1, \mathrm{PE} \rightarrow \mathrm{BI})$. This result concludes that teachers have positive intentions towards the utilization of the MCL-based CPD system. The MCL system is more likely to be used by teachers if they believe that the mobile collaborative learning interface is user-friendly, straightforward, and easy to use. The Effort Expectancy (EE) and Facilitating Conditions (FC) have a statistically significant effect on teachers' behavioral intention with values of $(\beta=0.255, p<0.001)$ and $(\beta=2.326, p<0.001)$, respectively. The obtained results support the hypotheses $(\mathrm{H} 2, \mathrm{EE} \rightarrow \mathrm{BI})$ and $(\mathrm{H} 3, \mathrm{FC} \rightarrow \mathrm{BI})$, respectively. The experimental results also indicate that the hedonic motivation (HM) and Mobility (M) have a significant impact on teachers' behavioral intention with $(\beta=-0.134, p<0.05)$ and $(\beta=-0.11, p<0.05)$, respectively, and thus satisfy the hypotheses $(\mathrm{H} 4, \mathrm{HM} \rightarrow \mathrm{BI})$ and $(\mathrm{H} 5, \mathrm{M} \rightarrow \mathrm{BI})$. These results prove that teachers find the MCL app entertaining, which may encourage them to participate in mobile-based collaborative learning activities. When creating learning applications for the professional development of teachers, app developers and designers should keep in mind excellent design concepts, as the apps are intended to be entertaining to use. The mobility construct is considered to be the most important factor in teachers' behavioral intentions toward MCL-based CPD acceptance when compared to other constructs. The results indicate that the ability to access MCL-based CPD from any location and at any time greatly encouraged the teachers to utilize it to provide teachers real-time support at the classroom level. Knowledge acquisition (KA) and Content and Information Quality (CIQ) constructs also proved to have a statistically significant impact on behavioral intention with $(\beta=0.109, p<0.05)$, and $(\beta=0.357, p<0.001)$, respectively, and as a result, hypotheses $(\mathrm{H} 6, \mathrm{KA} \rightarrow \mathrm{BI})$ and $(\mathrm{H} 7, \mathrm{CIQ} \rightarrow \mathrm{BI})$ are supported. These findings relate to the enhancements of the overall performance of teachers in terms of knowledge acquisition (i.e., propose innovative ideas, acquire novel skills and knowledge) and encouragement. The teachers have shown a significant interest in mobile technology for their professional development, as it improved their learning outcomes, learning new things regarding teaching methods, assessments techniques, and instructional planning. The MCL system helped the teacher in acquiring new knowledge through training and on-the-job support. Apart from this, content and information quality is a key factor of this research. The quality of content and information has a significant impact on behavioral intention, while instructors' views about the quality of content and information have a more dominating influence on users' satisfaction in terms of the system providing upto-date, relevant, comprehensive, easy to understand, and well-organized content and information. As a result, CPD-providing authorities should devote many resources to improve the content and information quality of mobile-based CPD systems.

The impact of the ongoing support has also been analyzed. The ongoing support helps to resolve on-job issues related to pedagogy, assessment, and content. The teachers think the support and facilitation provided by the system were very helpful to solve classroom-level issues and to easily share and obtain feedback from experts. To assess the impact of the system on the motivation of teachers in learning activities, the reward construct was analyzed. It was found that CPD rewards motivated the teachers and have a statistically significant impact on the behavioral intention in terms of performance. Experimental results show that on-job support (S) and Reward (R) constructs have a statistically significant impact on the behavioral intention with $(\beta=0.137, p<0.05)$ and $(\beta=0.128, p<0.05)$, respectively, and as a result $(\mathrm{H} 8, \mathrm{~S} \rightarrow \mathrm{BI})$ and $(\mathrm{H} 9, \mathrm{R} \rightarrow \mathrm{BI})$ are supported. The reward construct has improved the motivation and engagement of teacher educators affected in the post COVID-19 pandemic. 
The relationship between the interactivity with peers and experts (INT), engagement (ENG), and Self-Management (SM) in conjunction with collaborative learning (CL) has been investigated. Based on the findings, the connection between collaborative learning and interactivity with peers, interactivity with the instructors, engagement, and selfmanagement of learning has been favorably and substantially correlated with collaborative learning. These are significantly associated with collaborative learning (CL). Interactivity with peers, TEIs experts (INT) $(\beta=0.235, p<0.001)$, engagement (ENG) $(\beta=0.3 .991$, $p<0.001)$, and self-management (SM) $(\beta=0.08, p<0.05)$ support the hypotheses $(\mathrm{H} 11$, $\mathrm{INT} \rightarrow \mathrm{CL}),(\mathrm{H} 12, \mathrm{ENG} \rightarrow \mathrm{CL})$, and $(\mathrm{H} 13, \mathrm{SM} \rightarrow \mathrm{CL})$, respectively.

The findings show that the MCL-based CPD app enhances the professional learning experience with the vast majority of participants. The system helps teachers to be interactive and engaged with peers, their TEIs experts, and guides teachers to exchange information within cluster groups. The experimental results show that the system helps the teachers to be self-disciplined for their professional development and manage, organize and complete all CPD activities in a timely manner. In the end, the impact of collaborative learning (CL) on behavioral intention was assessed and it was found that CL has a significant effect on the behavioral intention $(\beta=0.205, p<0.001)$ and supports the hypothesis $(\mathrm{H} 10, \mathrm{CL} \rightarrow \mathrm{BI})$.

The findings of this research support the interaction and involvement of teachers and experts in mobile collaborative learning environments, which, in turn, has an impact on their professional achievement in the long run. The findings also revealed that PE, EE, HM, M, CL, ENG, INT, SM, S, R, CIQ, and KA all have significantly contributed to the acceptance of mobile collaborative learning. The findings may be helpful for teachers training institutions and other CPD providing agencies as they strive to adopt a mobile collaborative learning system.

Limitations: One of the limitations is the sample size, which is limited to public sector elementary school teachers only, while other cadre teachers such as primary school teachers, secondary school teachers, and subject specialists were not included. For future research, data from additional public and private schools might be acquired to validate and replicate current findings and to improve the generalizability of the research.

In addition, there is no data triangulation with the questionnaire. Teachers' perceptions are all that is considered. To include this, it is necessary to incorporate the perspectives of experts, peers, and guide teachers, among others. Furthermore, we have not included any moderators such as age, gender, experience, or qualifications in the framework for studying their effect on the proposed constructs, which may be useful in the future as well.

Author Contributions: The authors shared equal responsibility for the invention of the idea, the implementation and analysis of the experimental results, and the drafting of the text. All authors have read and agreed to the published version of the manuscript.

Funding: This research received no external funding.

Institutional Review Board Statement: Not applicable.

Informed Consent Statement: All subjects who took part in the study gave their informed consent.

Data Availability Statement: Not applicable.

Conflicts of Interest: The authors declare no conflict of interest.

\section{References}

1. Singh, A.K.; Rind, I.A.; Sabur, Z. Continuous Professional Development of School Teachers: Experiences of Bangladesh, India, and Pakistan. In Handbook of Education Systems in South Asia; Springer: New York, NY, USA, 2020; pp. 1-27.

2. Siddiqui, K.A.; Mughal, S.H.; Soomro, I.A.; Dool, M.A. Teacher Training in Pakistan: Overview of Challenges and their Suggested Solutions. IJORER Int. J. Recent Educ. Res. 2021, 2, 215-223. [CrossRef]

3. Chaudary, I.A. A new vision of professional development for tertiary teachers in Pakistan. Prof. Dev. Educ. 2011, 37, 633-637. [CrossRef] 
4. British Council. 2018 Continuing Professional Development (CPD) Options for Primary School Teachers (PSTs) at School and Local Level in Punjab. Available online: https://www.britishcouncil.pk/sites/default/files/cpd_options_for_psts_at_school_ and_local_level_in_punjab_-_british_council_2018.pdf (accessed on 20 August 2020).

5. GoP. 2009 National Professional Standards for Teachers in Pakistan. Available online: https://www.nacte.org.pk/assets/ download/NationalProfessionalStandardsforTeachersinPakistan.pdf (accessed on 17 January 2018).

6. GoP. 2009 The National Education Policy 2009. Available online: http://itacec.org/document/2015/7/National_Education_ Policy_2009.pdf (accessed on 29 October 2020).

7. SAHE. 2014 Education Monitor: Reviewing Quality of Key Education Inputs in Pakistan. Available online: www.sahe.org.pk/ wp-content/uploads/2016/01/4.-EM-I.compressed.pdf (accessed on 29 October 2020).

8. USAID-UNESCO. 2006 Strategic Framework for Teacher Education and Professional Development. Available online: https: / / files.eric.ed.gov / fulltext/ED497053.pdf (accessed on 29 October 2020).

9. Dahri, N.A.; Vighio, M.S.; Dahri, M.H. An Acceptance of Web Based Training System for Continuous Professional Development. A Case Study of Provincial Institute of Teacher Education Sindh, Nawabshah. In Proceedings of the 2018 3rd International Conference on Emerging Trends in Engineering, Sciences and Technology (ICEEST), Karachi, Pakistan, 21-22 December 2018; IEEE: Piscataway, NJ, USA, 2018; pp. 1-8.

10. Standardized Achievement Test, 2017 Standardized Achievement Test (SAT-V) Technical and Statistical Analysis Report of 2016-2017; Sukkur IBA: Sindh, Pakistan, 2017; Available online: http:/ / www.iba-suk.edu.pk/ (accessed on 29 October 2020).

11. Dahri, N.A.; Vighio, M.S.; Dahri, M.H. A survey on technology supported collaborative learning tools and techniques in teacher education. In Proceedings of the 2019 International Conference on Information Science and Communication Technology (ICISCT), Tashkent, Uzbekistan, 9-10 March 2019; IEEE: Piscataway, NJ, USA, 2019.

12. Government of Pakistan. Pakistan-National Education Policy Framework, Federal Ministry of Education and Professional Training: Islamabad, Pakistan. 2017. Available online: http:/ / www.aepam.edu.pk/ (accessed on 29 October 2020).

13. Government of Sindh. 2014 Sindh Education Sector Plan (SESP, 2014-2018) for the 2014-2018, Karachi. Available online: http:/ / www.Sindheducation.gos.pk (accessed on 15 December 2020).

14. Government of Sindh. 2009 Teacher Education Development Policy (TED, 2009), Karachi. Available online: http://www.Steda gos.pk (accessed on 15 June 2020).

15. Government of Pakistan. Digital Pakistan Policy. 2018. Available online: https://moitt.gov.pk/SiteImage/Misc/files/DIGITAL\% 20PAKISTAN\%20POLICY.pdf (accessed on 15 October 2020).

16. West Mark. Mobile Learning for Teachers: Global Themes; UNESCO: Paris, France, 2012; Volume 3.

17. Dykes, G.; Knight, H. Mobile Learning for Teachers in Europe: Exploring the Potential of Mobile Technologies to Support Teachers and Improve Practice; UNESCO: Paris, France, 2012.

18. Traxler, J.; Vosloo, S. Introduction: The prospects for mobile learning. Prospects 2014, 44, 13-28. [CrossRef]

19. Spar, B.; Dye, C.; Lefkowitz, R.; Pate, D. 2018 Workplace Learning Report: The Rise and Responsibility of Talent Development in the New Labor Market; LinkedIn Learning: Ojai, CA, USA, 2018.

20. Baran, E. Professional development for online and mobile learning: Promoting teachers' pedagogical inquiry. In Second Handbook of Information Technology in Primary and Secondary Education; Springer: New York, NY, USA, 2018; pp. 463-478.

21. USAID-UNICEF. 5-Year Progress Review of SDG 4-Education 2030 in Asia-Pacific. Available online: https: / /apasdg4education2 030.org/5-year-progress-review-sdg-4-education-2030-asia-pacific/ (accessed on 15 November 2021).

22. So, H.J. Turning on mobile learning in Asia: Illustrative initiatives and policy implications. Policy Focus: UNESCO Work. Pap. Ser. Mob. Learn. 2012, 1, 1-32.

23. Deriquito, M.; Domingo, Z. Mobile learning for teachers in Asia: Exploring the potential of mobile technologies to support teachers and improve practice. Teach. Focus UNESCO Work. Pap. Ser. Mob. Learn. 2012, 1-41.

24. Dillenbourg, P. What do you mean by collaborative learning? In Collaborative Learning: Cognitive and Computational Approaches; Elsevier: Amsterdam, The Netherlands, 1999; pp. 1-19.

25. STEDA. 2018 Continuous Professional Development (CPD) Model. Available online: http://www.sindheducation.gov.pk/ Contents /Menu/CPDModel.pdf (accessed on 29 October 2020).

26. Dillenbourg, P.; Järvelä, S.; Fischer, F. The evolution of research on computer-supported collaborative learning. In TechnologyEnhanced Learning; Springer: Dordrecht, The Netherlands, 2009; pp. 3-19.

27. Laal, M.; Ghodsi, S.M. Benefits of collaborative learning. Procedia-Soc. Behav. Sci. 2012, 31, 486-490. [CrossRef]

28. Fishbein, M.; Ajzen, I. Belief, Attitude, Intention and Behavior: An Introduction to Theory and Research; Adison-Wesley: Reading, MA, USA, 1975.

29. Venkatesh, V.; Morris, M.G.; Davis, G.B.; Davis, F.D. User acceptance of information technology: Toward a unified view. MIS Q. 2003, 27, 425-478. [CrossRef]

30. Davis, F.D.; Bagozzi, R.P.; Warshaw, P.R. User acceptance of computer technology: A comparison of two theoretical models. Manage. Sci. 1989, 35, 982-1003. [CrossRef]

31. Ajzen, I. The theory of planned behavior. Org. Behav. Hum. Decis. Process. 1991, 50, 179-211. [CrossRef]

32. Venkatesh, V. Determinants of perceived ease of use: Integrating control, intrinsic motivation, and emotion into the technology acceptance model. Inf. Syst. Res. 2000, 11, 342-365. [CrossRef] 
33. Venkatesh, V.; Thong, J.Y.; Xu, X. Consumer acceptance and use of information technology: Extending the unified theory of acceptance and use of technology. MIS Q. 2012, 36, 157-178. [CrossRef]

34. Almaiah, M.A.; Alamri, M.M.; Al-Rahmi, W. Applying the UTAUT Model to Explain the Students' Acceptance of Mobile Learning System in Higher Education. IEEE Access 2019, 7, 174673-174686. [CrossRef]

35. Terzis, V.; Economides, A.A. The acceptance and use of computer based assessment. Comput. Educ. 2011, 56, 1032-1044. [CrossRef]

36. Wang, Y.-S.; Liao, Y.-W. Assessing eGovernment systems success: A validation of the DeLone and McLean model of information systems success. Gov. Inf. Q. 2008, 25, 717-733. [CrossRef]

37. Peng, D. Mobile-Based Teacher Professional Training: Influence Factor of Technology Acceptance. In Foundations and Trends in Smart Learning; Springer: Singapore, 2019; pp. 161-170.

38. Al-Rahmi, W.M.; Othman, M.S. Evaluating student's satisfaction of using social media through collaborative learning in higher education. Int. J. Adv. Eng. Technol. 2013, 6, 1541.

39. Isaac, O.; Abdullah, Z.; Aldholay, A.H.; Ameen, A.A. Antecedents and outcomes of internet usage within organisations in Yemen: An extension of the Unified Theory of Acceptance and Use of Technology (UTAUT) model. Asia Pac. Manag. Rev. 2019, 24, 335-354. [CrossRef]

40. Fornell, C.; Larcker, D.F. Evaluating structural equation models with unobservable variables and measurement error. J. Mark. Res. 1981, 18, 39-50. [CrossRef]

41. Selvi, K. Motivating factors in online courses. Procedia Soc. Behav. Sci. 2010, 2, 819-824. [CrossRef]

42. Shroff, R.H.; Keyes, C.J. A proposed framework to understand the intrinsic motivation factors on university students' behavioral intention to use a mobile application for learning. J. Inf. Technol. Educ. Res. 2017, 16, 143-168. [CrossRef]

43. Alalwan, N.; Al-Rahmi, W.M.; Alfarraj, O.; Alzahrani, A.; Yahaya, N.; Al-Rahmi, A.M. Integrated Three Theories to Develop a Model of Factors Affecting Students' Academic Performance in Higher Education. IEEE Access 2019, 7, 98725-98742. [CrossRef]

44. Al Rahmi, W.M.; Othman, M.S.; Musa, M.A. The Improvement of Students' Academic Performance by Using Social Media through Collaborative Learning in Malaysian Higher Education. Asian Soc. Sci. 2014, 10, 210.

45. Arain, A.A.; Hussain, Z.; Vighio, M.S.; Rizvi, W.H. Factors Influencing Acceptance of Mobile Learning by Higher Education Students in Pakistan. SINDH Univ. Res. J. SCIENCE Ser. 2018, 50, 141-146. [CrossRef]

46. Marinkovic, V.; Kalinic, Z. Antecedents of customer satisfaction in mobile commerce: Exploring the moderating effect of customization. Online Inf. Rev. 2017, 41, 138-154. [CrossRef]

47. Akram, U.; Fülöp, M.; Tiron-Tudor, A.; Topor, D.; Căpușneanu, S. Impact of Digitalization on Customers' Well-Being in the Pandemic Period: Challenges and Opportunities for the Retail Industry. Int. J. Environ. Res. Public Heal. 2021, 18, 7533. [CrossRef] [PubMed]

48. Wang, Y.-S.; Wu, M.-C.; Wang, H.-Y. Investigating the determinants and age and gender differences in the acceptance of mobile learning. Br. J. Educ. Technol. 2009, 40, 92-118. [CrossRef]

49. Balkaya, S.; Akkucuk, U. Adoption and Use of Learning Management Systems in Education: The Role of Playfulness and Self-Management. Sustainability 2021, 13, 1127. [CrossRef]

50. Hair, J.F.; Sarstedt, M.; Ringle, C.M.; Mena, J.A. An assessment of the use of partial least squares structural equation modeling in marketing research. J. Acad. Mark. Sci. 2012, 40,414-433. [CrossRef]

51. Puriwat, W.; Tripopsakul, S. Explaining Social Media Adoption for a Business Purpose: An Application of the UTAUT Model. Sustainability 2021, 13, 2082. [CrossRef]

52. Bentler, P.M.; Chou, C.-P. Practical Issues in Structural Modeling. Sociol. Methods Res. 1987, 16, 78-117. [CrossRef]

53. Krejcie, R.V.; Morgan, D.W. Determining sample size for research activities. Educ. Psychol. Meas. 1970, 30, 607-610. [CrossRef]

54. Arain, A.A.; Hussain, Z.; Rizvi, W.H.; Vighio, M.S. Extending UTAUT2 toward acceptance of mobile learning in the context of higher education. Univers. Access Inf. Soc. 2019, 18, 659-673. [CrossRef]

55. Al-Rahmi, A.; Al-Rahmi, W.; Alturki, U.; Aldraiweesh, A.; Almutairy, S.; Al-Adwan, A. Exploring the Factors Affecting Mobile Learning for Sustainability in Higher Education. Sustainability 2021, 13, 7893. [CrossRef] 